\title{
Profil Kesiapan dan Pemahaman Guru Biologi terhadap Pelaksanaan Asesmen Psikomotorik dan Afektif Selama Pembelajaran Online di SMA Seluruh Kecamatan Comal, Pemalang
}

\author{
Eka Nunik Suharjanti ${ }^{1)}$, Ipah Budi Minarti ${ }^{2)}$ dan Lussana Rossita Dewi ${ }^{3)}$. \\ ${ }^{1,2,3}$ Program Studi Pendidikan Biologi, FPMIPATI, Universitas PGRI Semarang \\ 1email: ekanunik.s@gmail.com \\ ${ }^{2}$ email: ipeh_mi2n@yahoo.co.id \\ 3email: lussana82@gmail.com
}

\section{Naskah diterima tanggal 10 Agustus 2021, disetujui tanggal 23 November 2021, diterbitkan tanggal 30 November 2021}

\begin{abstract}
Assessment is part of a teacher's pedagogic competence and curriculum-13 must carry out cognitive, psychomotor and affective assessments. Online learning causes the implementation of psychomotor and affective assessments to be hampered. This study aims to determine the readiness and understanding of Biology teachers on psychomotor and affective assessments during online learning. The method used is qualitative with descriptive analysis. The sampling technique is a saturated sampling technique. The subject of the study, namely the Biology teacher of the SMA in Comal District, opened 5 teachers through filling out questionnaires distributed online on google forms and RPP documentation as well as evidence of the implementation of the assessment, while the student questionnaires were used as secondary data. Data analysis using descriptive analysis consists of reduction, data display, and verification. This study resulted in the finding that the teacher's assessment readiness profile during online learning can be declared ready to carry out psychomotor and affective assessments. Meanwhile, the profile of teachers' understanding of psychomotor and affective assessments can generally be obtained at a low level. An understanding profile that has an impact on misconceptions in the realm of assessment and the development of an assessment rubric that is not yet good so that human application cannot run optimally. In addition, the application of psychomotor and affective assessments during online learning is influenced by the factors of the teacher's IT ability and the facilities owned by the students.
\end{abstract}

Key words : Readiness, Understanding, Psychomotor Assessment, Affective Assessment

\section{PENDAHULUAN}

Undang-Undang Nomor 14 Tahun 2005 tentang Guru dan Dosen Pasal 10 ayat (1) bahwa guru harus memiliki 4 kompetensi yaitu kompetensi pedagogik, kompetensi kepribadian, kompetensi sosial, dan kompetensi profesional. Kompetensi pedagogik meliputi pemahaman guru terhadap peserta didik, kemampuan guru melaksanakan proses pembelajaran meliputi perencanaan, pelaksanaan, penilaian dan mengevaluasi peserta didik. Penilaian (asesmen) dan evaluasi merupakan istilah yang hampir sama, namun sebenarnya merupakan hal yang berbeda.

Asesmen adalah proses pengumpulan informasi yang dilakukan dengan berbagai cara untuk mengetahui kemajuan dan ketercapaian kompetensi peserta didik. Sedangkan evaluasi merupakan suatu proses sistematis untuk mengetahui efisiensi kegiatan belajar mengajar (Rosidin, 2017). Kata "penilaian" lebih dekat pengertiannya pada assessment bukan evaluation. Sedangkan evaluation artinya evaluasi, sebagai kegiatan pengendalian mutu pendidikan (Yusuf, 2017). Jadi asesmen merupakan bagian dari kegiatan evaluasi, hasil penilaian digunakan untuk evaluasi dan ditindaklanjuti untuk meningkatkan mutu pembelajaran. Asesmen pembelajaran peserta didik sangat penting dilakukan karena akan mempengaruhi proses pembelajaran selanjutnya (Basuki \& Hariyanto, 2015). Ranah asesmen memiliki peran sama pentingnya, terdiri dari tiga kompetensi yaitu asesmen kognitif, asesmen psikomotorik, dan asesmen afektif.

Pandemi virus Corona yang meluas di Indonesia secara massif dimulai bulan Maret tahun 2020 sangat berdampak pada pola tatanan kehidupan. Salah satu dampak dari pandemi COVID-19 yaitu pelaksanaan pendidikan. Kebijakan dengan dikeluarkannya Surat Edaran Nomor 4 Tahun 2020 tentang Pelaksanaan Kebijakan Pendidikan dalam Masa Darurat Penyebaran Coronavirus Disease (COVID-19). Langkah tersebut dilakukan untuk menekan dan meminimalisir angka pasien yang terpapar virus. Surat Edaran berisi salah satunya pembelajaran (c) 2021 Florea: Jurnal Biologi dan Pembelajarannya 89 
dilakukan secara online. Kebijakan proses belajar di rumah dinilai tepat untuk menghindari penyebaran virus semakin meluas (I. F. Ahmad, 2020). Pemberlakuan kebijakan tersebut mengharuskan sekolah mempersiapkan skema baru yang berbasis pendidikan teknologi informasi dan komunikasi dalam pembelajaran dari rumah (Setyowahyudi \& Ferdiyanti, 2020).

Pembelajaran dari rumah tetap dilaksanakan untuk semua mata pelajaran, salah satunya yaitu mata pelajaran Biologi. Pada mata pelajaran Biologi berhubungan dengan langkah mengamati alam secara sistematis, bukan hanya penguasaan kumpulan pengetahuan yang berupa fakta, konsep, atau prinsip saja (Hidayah, 2017). Biologi merupakan suatu proses penemuan dan penerapan di kehidupan. Berdasarkan hal tersebut pembelajaran Biologi merupakan sarana strategis dalam mengembangkan keterampilan dan sikap ilmiah peserta didik. Guru perlu melakukan penilaian yang objektif, terpadu, ekonomis, transparan, akuntabel dan edukatif (Zuhera et al., 2017). Perlu adanya refleksi terhadap pembelajaran yang telah berlangsung karena inti dari proses pendidikan adalah kualitas pembelajaran (Lestari, 2020). Prestasi belajar, keterampilan dan perubahan tingkah laku ataupun karakter peserta didik adalah produk dari proses pembelajaran.

Pelaksanaan asesmen kepada peserta didik selama pandemi kurang bisa dilaksanakan dengan baik, kendala terjadi karena keterbatasan waktu, hambatan dari peserta didik sendiri, dan fasilitas (Yansa \& Retnawati, 2021). Pada masa pandemi, asesmen dapat diterapkan dengan adanya teknologi yaitu jaringan internet ataupun kuota (Taufik, 2019). Berdasarkan observasi awal, guru Biologi di SMA wilayah Comal cenderung melaksanakan asesmen kognitif terhadap peserta didik, sedangkan asesmen psikomotorik dan afektif jarang dilakukan. Padahal asesmen psikomotorik dan afektif sama penting untuk dilaksanakan karena pembelajaran sains menuntut keterlibatan peserta didik secara aktif (Kurniawati et al., 2014). Keterampilan pada mata pelajaran biologi seperti keterampilan dalam kegiatan praktikum dan aspek afektif seperti perubahan sikap peserta didik menjadi sulit diamati. Berbagai keterbatasan komunikasi melalui media digital menyebabkan tidak bisa leluasa melaksanakan asesmen. Hal ini mendorong untuk dilaksanakan penelitian untuk mengetahui 1) profil kesiapan guru Biologi terhadap pelaksanaan asesmen psikomotorik dan afektif selama pembelajaran online di SMA wilayah Kecamatan Comal; 2) profil pemahaman guru Biologi terhadap asesmen psikomotorik dan afektif selama pembelajaran online di SMA wilayah Kecamatan Comal; dan 3) solusi yang dapat dilaksanakan untuk meningkatkan profil kesiapan dan pemahaman asesmen guru Biologi terhadap asesmen psikomotorik dan afektif.

\section{METODE}

Metode penelitian menggunakan deskriptif kualititaif. Populasi pada penelitian adalah guru Biologi SMA di wilayah Kecamatan Comal. Teknik sampling jenuh (Mulyatiningsih, 2011) digunakan pada penelitian ini karena jumlah populasi terdiri dari 5 guru Biologi yang berasal dari 3 SMA di wilayah Kecamatan Comal. Teknik pengumpulan data yang digunakan yaitu kuesioner secara online, wawancara, dan pengumpulan dokumentasi berupa dokumen RPP guru serta bukti-bukti fisik pelaksanaan asesmen psikomotorik dan afektif. Analisis pada penelitian ini menggunakan metode kualitatif sehingga analisisnya lebih banyak berupa deskriptif dari pada statistik. Teknik analisis terdiri dari reduction, display data, dan verification (Sari \& Setiawan, 2020) (Sugiyono, 2015).

\section{HASIL DAN PEMBAHASAN}

\section{Profil Kesiapan Guru Biologi dalam Melaksanakan Asesmen Psikomotorik dan Afektif selama Pembelajaran Online}

Proses pembelajaran yang dilaksanakan secara online mengharuskan pendidik menggunakan berbagai media pembelajaran dan teknologi agar pembelajaran tetap dapat terlaksana. Asesmen salah satu aspek yang harus dilaksanakan pada pembelajaran online. Asesmen psikomotorik dan afektif memiliki teknik pelaksanaan yang berbeda daripada asesmen kognitif. Hal ini disebabkan karena pelaksanaan asesmen psikomotorik dan afektif memerlukan waktu lama serta memantau secara langsung terhadap proses dan hasil belajar peserta didik.

Tabel 1. Kesiapan Guru dalam Melaksanakan Asesmen Psikomotorik dan Afektif selama Pembelajaran Online berdasarkan Analisis RPP.

\begin{tabular}{ccc}
\hline Responden & Hasil Analisis (\%) & $\begin{array}{c}\text { Kriteria } \\
\text { Kesiapan }\end{array}$ \\
\hline A & 66,7 & Siap \\
B & 64,6 & Siap \\
C & 58,3 & Cukup siap \\
D & 87,5 & Sangat siap \\
E & 52,1 & Cukup siap \\
Rata-rata & 65,84 & Siap \\
\hline
\end{tabular}

(c) 2021 Florea: Jurnal Biologi dan Pembelajarannya 
Profil kesiapan guru dalam pelaksanaan asesmen psikomotorik dan afektif ditinjau dari dokumen instrumen menunjukkan presentase kesiapan yang berbeda-beda. Hal ini dapat terlihat pada Tabel 1 dengan penentuan kriteria kesiapan berpedoman pada Tabel 2 berdasarkan interval presentase yang diperoleh. Profil kesiapan guru dalam asesmen psikomotorik dan afektif pada pembelajaran online secara umum berada pada kategori siap dengan rerata $65,84 \%$.

Tabel 2. Range Presentase dan Kriteria Kualitatif Data (D. Agustin et al., 2015)

\begin{tabular}{ccc}
\hline No. & Interval (\%) & Kriteria Kesiapan \\
\hline 1. & $80,1-100$ & Sangat siap \\
2. & $60,1-80$ & Siap \\
3. & $40,1-60$ & Cukup siap \\
4. & $20,1-40$ & Kurang siap \\
5. & $0-20$ & Tidak siap \\
\hline
\end{tabular}

Kesiapan guru dalam perencanaan pelaksanaan asesmen yang ditinjau dari instrumen asesmen pada dokumen RPP, menunjukkan bahwa setiap guru pada dasarnya telah mempersiapkan dan merancang asesmen psikomotorik dan afektif yang akan dilaksanakan. Namun, masih terdapat instrumen yang belum lengkap, miskonsepsi dalam merumuskan rubrik penilaian, rubrik yang tidak lengkap, dan beberapa hal kurang sinkron dengan asesmen yang nyata dilaksanakan.

Dokumen RPP responden A dan responden E memiliki rubrik penilaian yang belum lengkap dan belum terdapat kriteria penilaian yang jelas. Contoh rubrik penilaian yang terdapat miskonsepsi yaitu pada dokumen RPP responden B dan responden C. Asesmen psikomotorik direncanakan melalui praktikum, tetapi objek yang dinilai berupa hasil laporan praktikum. Hal ini kurang sesuai karena laporan praktikum bersifat pengukuran ranah kognitif (Sudrajat et al., 2011). Laporan praktikum digunakan dapat mengetahui tingkat pemahaman peserta didik terhadap suatu materi yang dipraktikumkan, tetapi tidak dapat mengukur keterampilannya. Psikomotorik seharusnya penilaian yang dilakukan dengan mengamati kegiatan peserta didik dalam melakukan sesuatu yang melibatkan gerak tubuh (I. D. Agustin et al., 2018). Pada kegiatan praktikum seharusnya psikomotorik yang dinilai berupa keterampilan selama pelaksanaan praktikum, bukan dari hasil laporan. Jadi masih terdapat miskonsepsi dari instrumen asesmen psikomotorik yang dipersiapkan. Dokumen RPP responden D memiliki rubrik penilaian yang lengkap dan detail terhadap asesmen psikomotorik dan afektif.
Selama pembelajaran online asesmen afektif yang cenderung selalu dilaksanakan yaitu kehadiran dan kedisiplinan dalam mengumpulkan tugas. Keterlaksanaan asesmen psikomotorik dan afektif dipengaruhi oleh berbagai faktor baik dari peserta didik ataupun kesiapan dari masing-masing guru. Faktor yang berasal dari peserta didik yaitu keterbatasan fasilitas. Berdasarkan keterangan guru, belum tentu peserta didik memiliki HP yang memadai untuk mengikuti pembelajaran online. Sehingga sangat jarang pelaksanaan pembelajaran menggunakan media video conference. Hal ini menyebabkan proses pemantauan keterampilan dan perubahan sikap atau karakter peserta didik tidak dapat terlaksana dengan baik. Bahkan pembelajaran dengan menggunakan chating melalui google classs dan whatsapp tidak dapat membantu guru untuk melaksanakan asesmen.

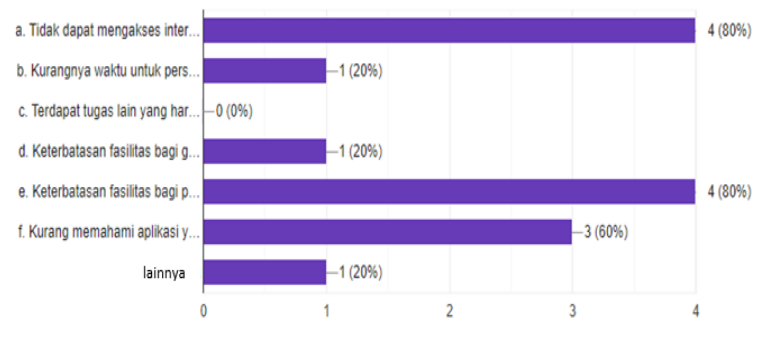

Gambar 1. Faktor-faktor yang mempengaruhi pelaksanaan asesmen psikomotorik dan afektif

Beberapa faktor mempengaruhi pelaksanaan asesmen selama pembelajaran online, faktor paling dominan yaitu tidak dapat mengakses internet dan keterbatasan fasilitas bagi peserta didik (Gambar 1), di mana kedua faktor tersebut sama-sama menunjukkan presentase sebesar $80 \%$. Diikuti dengan faktor kurangnya memahami aplikasi yang dapat dimanfaatkan untuk asesmen sebesar $60 \%$.

Guru beranggapan bahwa memerlukan waktu dan ketrampilan khusus dalam menyusun asesmen pembelajaran dengan aplikasi tertentu. Selain itu, perlu mempersiapkan lembar kerja siswa terlebih dahulu yang harus dikoneksikan ke jaringan internet. Meskipun pembelajaran online telah berjalan selama 1 tahun 3 bulan, namun kenyataan bahwa guru masih belum terbiasa dengan aplikasi penunjang masih ditemukan. Guru merasa kesulitan dalam mengakses aplikasi pendukung pelaksanaan asesmen disebabkan oleh penguasaan IT yang masih lemah, perlu memahami aplikasi terlebih dahulu dirasa banyak menyita waktu dan ketersediaan teknologi pendukung di setiap sekolah yang kurang. Sebenarnya faktor pemahaman guru mengenai asesmen juga mempengaruhi penerapan 
asesmen tidak hanya dari keterbatasan penguasaan teknologi informasi.

Praktikum menjadi hal yang tidak dapat terpisahkan dari pembelajaran Biologi. Selain itu, praktikum dapat menjadi wadah yang kompleks untuk melaksanakan asesmen psikomotorik dan afektif. Selama pembelajaran online sebagian guru yang pernah melaksanakan praktikum (Gambar 2). Data tersebut didukung oleh jawaban peserta didik (Gambar 3) mengenai pelaksanaan praktikum selama pembelajaran online. Pada kedua gambar sama-sama menunjukkan presentase praktikum $60 \%$ artinya terdapat 3 guru dan 30 peserta didik yang pernah melaksanakan praktikum.

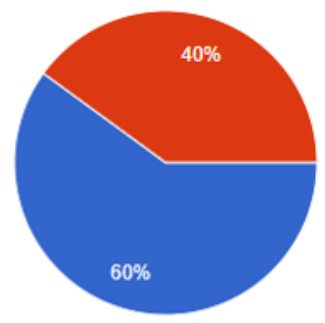

a. Pernah

b. Tidak pernah

Gambar 2. Pelaksanaan praktikum selama pembelajaran online berdasarkan angket guru

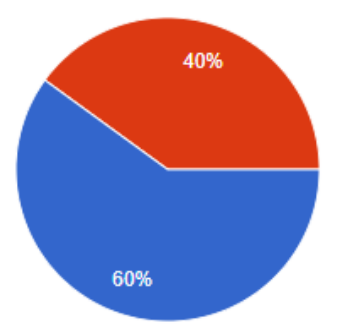

a. Pernah

b. Tidak pernah

Gambar 3. Pelaksanaan praktikum selama pembelajaran online berdasarkan angket peserta didik

Meskipun guru memberikan tugas untuk praktikum, pelaksanaan praktikum tersebut tidak dapat diamati untuk menjadi bagian dari asesmen psikomotorik dan afektif. Namun hasil dari praktikum peserta didik diamati oleh guru sebagai asesmen. Hal tersebut kurang sesuai dengan pengertian asesmen, yaitu suatu proses mengambil keputusan dengan menggunakan informasi yang diperoleh melalui pengukuran belajar, baik menggunakan instrumen tes maupun non tes yang meliputi proses belajar dan hasil belajar (Wahyudi, 2012). Asesmen proses dan hasil belajar saling berkaitan karena hasil merupakan akibat dari proses. Jadi akan lebih efektif dan efisien apabila dilaksanakan asesmen pada kedua hal tersebut karena dapat digunakan sebagai bahan evaluasi pembelajaran. Namun, karena keterbatasan ruang, komunikasi dua arah tidak dapat berjalan baik, dan tidak dapat memantau secara langsung sehingga hanya dari hasil praktikum dan foto lampiran yang digunakan oleh guru sebagai media pelaksanaan asesmen psikomotorik dan afektif. Sebenarnya proses pelaksanaan praktikum dapat diamati apabila guru memberikan tugas untuk merekam dan mengumpulkan rekaman proses praktikum. Hal ini tidak dilakukan oleh guru karena beberapa faktor. Tugas merekam proses praktikum dianggap memberatkan peserta didik, dikarenakan saat peserta didik melaksanakan praktikum secara individu akan kesulitan merekam kegiatan yang sedang dilakukan sendiri, kualitas kamera HP peserta didik yang kurang mencukupi, dan keterbatasan penyimpanan HP peserta didik.

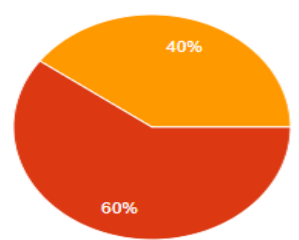

a. Tidak pernah

b. Dua bulan sekali

c. Satu bulan sekali

d. Setiap dua minggu sekal - e. Setiap minggu seka

Gambar 4. Intensitas pelaksanaan asesmen psikomotorik oleh guru

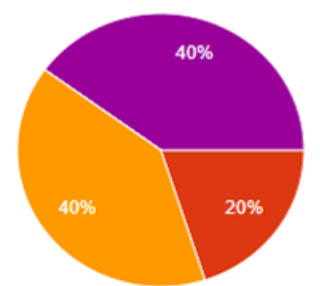

a. Tidak pernah

b. Dua bulan sekali

c. Satu bulan sekali

d. Setiap dua minggu sekal

- e. Setiap minggu sekali

Gambar 5. Intensitas pelaksanaan asesmen afektif oleh guru

Pelaksanaan asesmen psikomotorik dan afektif masing-masing guru berbeda sesuai dengan kebutuhan. Intensitas pelaksanaan asesmen psikomotorik (Gambar 4) yaitu sebesar $60 \%$ guru melaksanakan setiap dua bulan sekali, sedangkan 40\% guru melaksanakan setiap satu bulan sekali. Berbeda dengan intensitas pelaksanaan asesmen afektif (Gambar 5) yang terdapat $40 \%$ guru melaksanakan setiap satu minggu sekali, $40 \%$ guru melaksanakan dua bulan sekali, dan 20\% guru melaksanakan dua bulan sekali. Idealnya siklus asesmen proses dilakukan terus menerus pada setiap pertemuan dengan mengacu indikator, sedangkan asesmen hasil belajar dilakukan minimal setelah satu kompetensi dasar dipelajari (Rahman, 2017). 
Asesmen psikomotorik dan afektif mencakup proses pembelajaran pada setiap pertemuan yang dilakukan pada awal, pertengahan atau akhir pertemuan. Kemudian hasil asesmen ini menjadi bahan acuan bagi guru dalam menentukan langkah pembelajaran berikutnya.
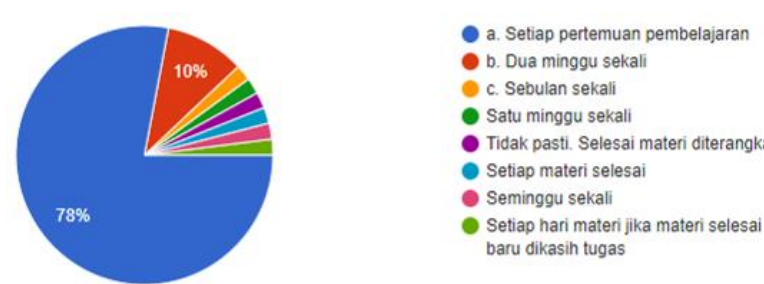

Gambar 6. Intensitas tugas yang diterima oleh peserta didik

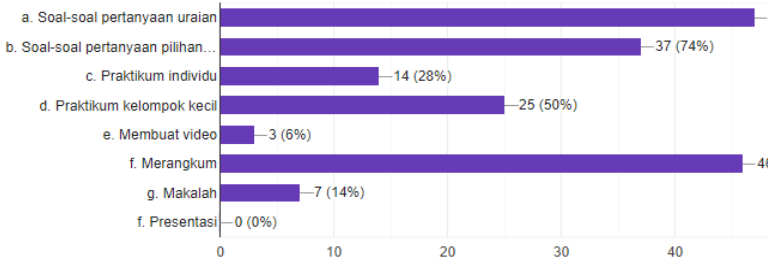

Gambar 7. Jenis tugas yang diterima oleh peserta didik

Asesmen psikomotorik dan afektif yang tidak selalu dilaksanakan setiap pertemuan pembelajaran sejalan dengan intensitas pemberian tugas dan jenis tugas yang diterima oleh peserta didik. Hal ini dapat terlihat pada Gambar 6 dan Gambar 7, di mana 78\% peserta didik menjawab selalu mendapatkan tugas setiap pembelajaran, namun tugas sebagian besar berupa tugas soal uraian dan merangkum. Presentase tugas soal uraian $94 \%$, tugas merangkum $92 \%$, soal pilihan ganda $74 \%$, praktikum $78 \%$, membuat makalah $14 \%$, membuat video $6 \%$ dan tidak terdapat tugas presentasi $(0 \%)$. Berdasarkan data tersebut, peserta didik lebih sering menerima tugas yang cenderung mengukur kemampuan kognitif. Sedangkan tugas yang melatih keterampilan jarang diberikan, hal ini menunjukkan kesempatan melaksanakan asesmen psikomotorik semakin sedikit.

Asesmen afektif lebih bersifat fleksibel karena dapat dilaksanakan secara non formal dengan mengamati karakter peserta didik, serta dapat dilaksanakan berdampingan dengan pelaksanaan asesmen kognitif maupun psikomotorik. Namun sebagian guru tidak selalu melaksanakan secara teratur pada setiap pertemuan pembelajaran disebabkan oleh keterbatasan waktu dan kemampuan. Pelaksanaan asesmen psikomotorik dan afektif setiap guru berbeda-beda sesuai dengan kebutuhan. Berdasarkan keterangan guru intensitas pelaksanaan asesmen psikomotorik (Gambar 7) dilaksanakan setiap dua bulan sekali ataupun setiap satu bulan sekali. Sedangkan intensitas asesmen afektif (Gambar 8) dilaksanakan setiap satu minggu sekali, dua bulan sekali, ataupun dua bulan sekali.

Beberapa faktor perlu untuk diperbaiki agar dapat melaksanakan asesmen psikomotorik dan afektif lebih baik selama pembelajaran online. Berdasarkan pendapat guru terdapat hal-hal yang perlu untuk diperbaiki yaitu 1) pengetahuan/keahlian dalam IT karena perlu adanya aplikasi yang lebih bagus sehingga pembelajaran online tetapi berjalan seperti tatap muka; 2) memperbaiki untuk selalu menjaga komunikasi 2 arah dengan peserta didik; 3) pengembangan pengetahuan media; dan 4) fasilitas yang harus ${ }^{4}$ memadai. Namun salah seorang guru berpendapat bahwa bukan pada perbaikan alat atau media, karena asesmen pembelajaran tatap muka pun tidak dapat terlaksana seperti yang diharapkan, apalagi pada saat pembelajaran online. Perbaikan pada diri sendiri dan konsistensi yang lebih utama untuk melaksanakan asesmen pembelajaran.

Berdasarkan pemaparan temuan hasil penelitian terkait profil kesiapan guru Biologi tentang asesmen psikomotorik dan afektif di SMA Kecamatan Comal selama pembelajaran online dapat dikatakan bahwa secara umum tingkat kesiapan guru berada pada kategori siap. Namun, beberapa faktor mempengaruhi penerapan asesmen tidak berjalan seluruhnya. Tidak terlaksananya asesmen psikomotorik dan afektif dengan baik sebenarnya berimbas terhadap peserta didik karena tidak ada evaluasi pembelajaran yang menjadi pertimbangan untuk pelaksanaan pembelajaran berikutnya. Hal ini merugikan peserta didik karena siklus pembelajaran tetap sama tanpa ada perubahan menjadi lebih baik sesuai kebutuhan peserta didik. Selain itu, alat penilaian yang kurang sesuai merugikan peserta didik karena tidak dapat mengenali dengan jelas peserta didik yang memang memiliki keterampilan dan sikap baik. Tidak perlu diragukan bahwa pembelajaran yang efektif, efesien dan produktif tidak mungkin ada tanpa asesmen yang baik (Sudrajat et al., 2011).

\section{Profil Pemahaman Guru Biologi terhadap Asesmen Psikomotorik dan Afektif}

Tingkat pemahaman guru Biologi tentang asesmen psikomotorik dan afektif di SMA Kecamatan Comal dilakukan berdasarkan skor jawaban benar pada Tabel 3 menunjukkan bahwa 
secara umum berada pada tingkat pemahaman rendah. Selain itu, didukung dengan analisis instrumen dan rubrik asesmen yang terdapat pada dokumen RPP. Penentuan tingkat pemahaman guru mengacu pada Tabel 4.

Tingkat pemahaman rendah mempengaruhi kesiapan dan pelaksanaan asesmen (Metin, 2013). Berdasarkan analisis dokumen RPP dapat dikatakan responden memiliki instrumen tetapi tidak semuanya diterapkan. Hal ini karena pemahaman guru terhadap asesmen masih tergolong rendah, padahal tuntutan Kurikulum 2013 mengharuskan melaksanakan asesmen dari 3 aspek yaitu asesmen kognitif, psikomotorik, dan afektif (Nurhaifa et al., 2020).

Meskipun profil kesiapan guru berada pada kategori siap, namun pemahaman guru terhadap asesmen rendah. Hal ini memunculkan kemungkinan bahwa instrumen yang telah dipersiapkan guru diperoleh melalui studi literasi dan menggunakan hasil tersebut untuk melengkapi dokumen perangkat pembelajaran tanpa disesuaikan dengan karakteristik materi dan kompetensi yang akan diukur. Selain itu, tuntutan kelengkapan dokumen dari kurikulum menjadi alasan instrumen asesmen dibuat. Analisis RPP menunjukkan adanya miskonsepsi pemahaman mengenai ranah asesmen kognitif, psikomotorik, dan afektif. Selain itu, ditemukan rubrik-rubrik penilaian yang belum dapat dikatakan baik karena belum memenuhi syarat. Rubrik yang baik harus mampu menghilangkan perbedaan terhadap skor yang sama terhadap pengamatan objek yang dilakukan pada waktu yang sama melalui deskripsi yang jelas (Hamdu \& Suryani, 2019).

Tabel 4. Range dan Kriteria Kualitatif Data (M. Ahmad \& Nasution, 2018)

\begin{tabular}{ccc}
\hline No. & Interval & $\begin{array}{c}\text { Tingkat } \\
\text { Pemahaman }\end{array}$ \\
\hline 1. & $80,1-$ & Tinggi \\
& 100 & Sedang \\
2. & $65,1-80$ & Rendah \\
3. & $<65$ & \\
\hline
\end{tabular}

Tabel 3. Pemahaman Guru terhadap Asesmen Psikomotorik dan Afektif

\begin{tabular}{|c|c|c|c|c|c|}
\hline Responden & $\begin{array}{l}\text { Skor Pilihan } \\
\text { Ganda }\end{array}$ & $\begin{array}{l}\text { Skor } \\
\text { Uraian }\end{array}$ & $\begin{array}{l}\text { Jumlah } \\
\text { Skor }\end{array}$ & $\begin{array}{r}\text { Total Nilai } \\
\text { (jumlah skor x 5) }\end{array}$ & $\begin{array}{r}\text { Tingkat } \\
\text { Pemahaman }\end{array}$ \\
\hline $\mathrm{A}$ & 8 & 2 & 10 & 50 & Rendah \\
\hline B & 8 & 3,5 & 11,5 & 57,5 & Rendah \\
\hline $\mathrm{C}$ & 8 & 3,5 & 11,5 & 57,5 & Rendah \\
\hline $\mathrm{D}$ & 9 & 4,5 & 13,5 & 67,5 & Sedang \\
\hline $\mathrm{E}$ & 7 & 3,5 & 10,5 & 52,5 & Rendah \\
\hline Rata-rata & & & & 57 & Rendah \\
\hline
\end{tabular}

Rubrik penilaian yang ideal seharusnya

Apabila guru mengalami kesulitan dalam menyusun rubrik menyebabkan guru kadang tidak menggunakan instrumen untuk melakukan asesmen terhadap peserta didik, sehingga penilaian cenderung subjektif karena tidak ada instrumen tertulis (Rosdiana \& Retnawati, 2014). Untuk mengatasi hal tersebut, perlu adanya instrumen asesmen psikomotorik dan afektif yang tepat disertai petunjuk, rubrik, dan kriteria penilaian jelas sehingga membantu guru dalam melakukan asesmen.

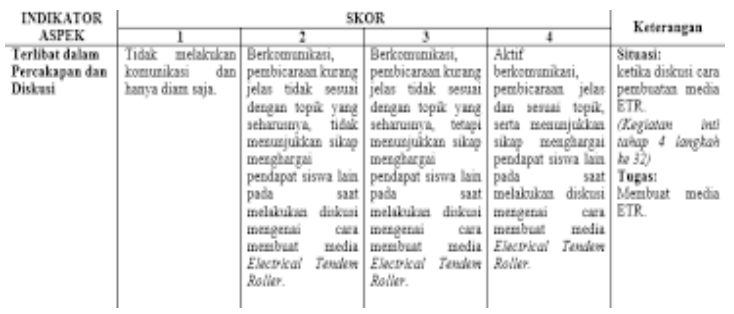

Gambar 8. Contoh rubrik psikomotorik dan afektif yang baik (Nurhaifa et al., 2020) mampu menghilangkan perbedaan terhadap skor yang sama dari pengamatan objek yang dilakukan pada waktu yang sama melalui deskripsi yang jelas (Hamdu \& Suryani, 2019). Jadi sangat perlu adanya penjelasan kriteria penskoran yang dideskripsikan dengan jelas sehingga mempermudah proses penilaian. Rubrik yang baik (Gambar 8) setidaknya memuat aspek kinerja, kriteria kinerja peserta didik, indikator penilaian yang terdiri dari kolom skor dan kolom deskripsi, serta keterangan waktu (Nurhaifa et al., 2020).

Asesmen psikomotorik adalah penilaian untuk mengetahui kemampuan peserta didik dalam menerapkan pengetahuan (Rosidin, 2017). Asesmen psikomotorik dicirikan adanya aktivitas fisik dan keterampilan kinerja. Ranah psikomotorik berhubungan dengan proses dan hasil belajar yang pencapaiannya melalui keterampilan yang melibatkan otot dan kekuatan fisik (Basuki \& Hariyanto, 2015). Berdasarkan pengertian tersebut, pelaksanaan 
asesmen psikomotorik melibatkan proses dan hasil dari kegiatan fisik. Namun pada kenyataan di lapangan tampak bahwa asesmen psikomotorik selama pembelajaran online oleh guru Biologi Kecamatan Comal hanya dinilai berdasarkan hasil laporan praktikum. Sebenarnnya laporan bersifat kognitif karena dapat mengetahui pemahaman peserta didik terhadap materi praktikum (Sudrajat et al., 2011). Padahal apabila seorang peserta didik mampu membuat laporan dengan baik belum tentu memiliki keterampilan praktikum yang baik, begitu juga sebaliknya. Jadi masih terdapat miskonsepsi dari guru yang beranggapan bahwa asesmen psikomotorik dapat dilakukan melalui penilaian hasil laporan praktikum. Selain itu, ditemukan instrumen psikomotorik dengan rubrik penilaian yang belum dapat dikatakan baik (Gambar 9).
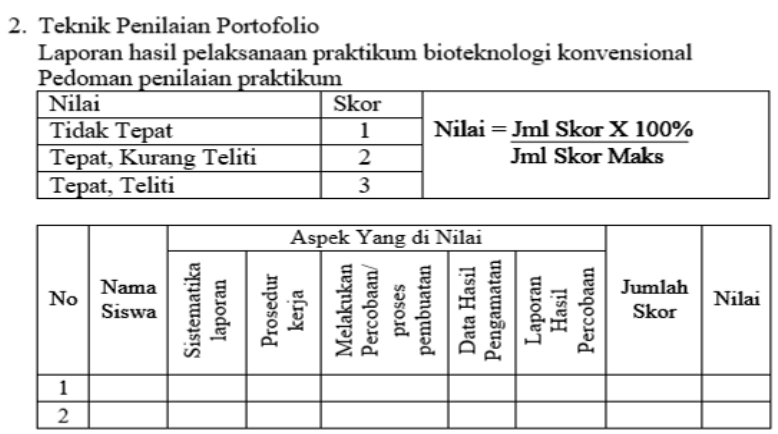

Gambar 9. Contoh instrumen psikomotorik dari dokumen RPP pada aspek penilaian terdapat miskonsepsi dan rubrik yang belum baik

Pada instrumen salah seorang guru tersebut mendukung bahwa pemahaman asesmen rendah dapat mengakibatkan adanya miskonsepsi aspek penilaian dan rubrik penilaian yang belum baik. Merujuk pada pengertian dari asesmen psikomotorik, maka pada contoh instrumen dapat dikatakan bahwa 5 aspek yang tertulis tidak termasuk ranah psikomotorik tetapi masuk dalam ranah kognitif. Selain itu, pedoman penilaian yang tertera belum memiliki rubrik penilaian yang jelas. Kriteria yang ada hanya berupa tepat, teliti, kurang teliti, dan tidak tepat. Kriteria tersebut masih digunakan untuk menafsirkan 5 aspek sekaligus dan belum dapat menjelaskan bagaimana proses yang seharusnya dinilai kemudian mendapat poin 1, 2, ataupun 3. Jadi masih memerlukan keterangan lebih lanjut mengenai kriteria kinerja peserta didik dari masing-masing aspek yang akan dinilai.

Asesmen afektif merupakan kegiatan yang dilakukan pendidik memperoleh informasi deskriptif mengenai perilaku peserta didik dalam masyarakat, kelas, dan rumah. Ranah afektif di antaranya yaitu sikap, minat, konsep diri, nilai, moral, emosi, hubungan sosial, opini, motivasi diri, dan sebagainya (Basuki \& Hariyanto, 2015). Merujuk pada pengertian tersebut, maka analisis beberapa instrumen asesmen afektif dari dokumen RPP terdapat instrumen yang memiliki aspek-aspek penilaian lebih dari satu aspek. Namun, instrumen belum memiliki kejelasan rubrik penilaian (Gambar 10).

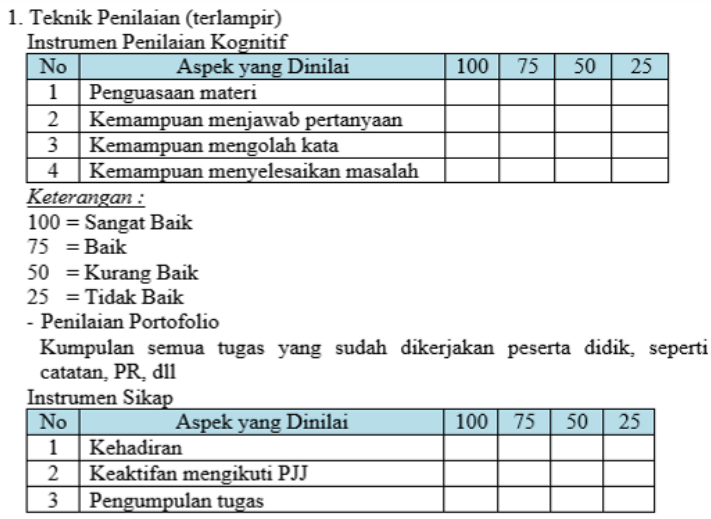

2. Pembelajaran Remedial dan Pengayaan

Bagi peserta didik yang belum memenuhi kriteria ketuntasan minimal (KKM), maka guru bisa memberikan soal tambahan

Gambar 10. Contoh instrumen afektif dari dokumen RPP beserta rubrik penilaiannya

Contoh instrumen tersebut hanya memiliki 3 aspek yang dinilai, aspek penilaian afektif akan menyeluruh jika dilengkapi dengan aspek-aspek yang lain. Misalnya kejujuran mengerjakan tugas, tidak mencontoh tugas teman, kesopanan, cara berkomunikasi, dan sebagainya. Selain itu, instrumen tersebut juga belum memiliki rubrik penilaian yang jelas dan mudah dilaksanakan. Hal seperti inilah yang menyebabkan penerapan asesmen tidak terlaksana dengan baik karena masih minimnya rubrik yang disiapkan. Padahal fungsi dari rubrik sangat penting, yaitu memudahkan proses dalam memberikan penilaian masing-masing aspek terhadap seluruh peserta didik.

Responden D (Gambar 11) memiliki instrumen yang baik, karena selain memiliki aspek penilaian juga terdapat rubrik penilaian 
yang baik dan jelas. Rubrik dapat dikatakan jelas karena terdapat deskripsi dari kriteria penskoran secara detail sehingga mempermudah proses penilaian. Pada instrumen tersebut terdapat 3 aspek penilaian afektif, yang mana setiap aspek memiliki kriteria penilaian berbeda. Pada instrumen penilaian tersedia 4 pilihan skor yang dideskripsikan secara kualitatif dalam kolom deskripsi. Adanya keterangan pada setiap poin memudahkan pemberian skor saat penerapan asesmen.

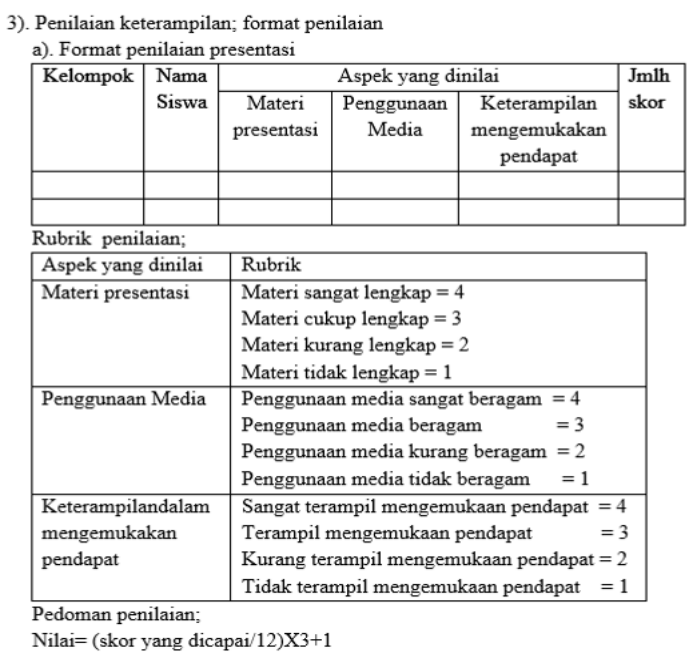

Gambar 11. Contoh instrumen asesmen dilengkapi rubrik yang jelas

Faktor yang mempengaruhi profil pemahaman guru terhadap asesmen psikomotorik dan afektif, di antaranya yiatu sumber literasi, informasi pendukung, dan pengarahan. Berdasarkan hasil kuesioner, guru memperoleh literasi asesmen dengan sumber paling dasar yaitu buku. Beberapa guru menambah wawasan mengenai asesmen melalui kegiatan workshop, pengarahan, dan seminar. Namun, kegiatan tersebut belum cukup membantu guru untuk menerapkan asesmen dengan baik selama pembelajaran online. Selain itu, guru Biologi wilayah Kecamatan Comal belum pernah mendapat sosialisasi atau pengarahan secara langsung dari Kemendikbud Pemalang mengenai asesmen psikomotorik dan afektif. Hal ini menyebabkan guru merasa Kemendikbud wilayah Pemalang belum cukup banyak memberikan informasi tentang asesmen khususnya asesmen psikomotorik dan afektif selama pandemi. Perubahan proses pembelajaran secara online masih menyulitkan guru karena belum dapat beradaptasi sepenuhnya.

Selain itu, guru belum memahami pentingnya pelaksanaan asesmen karena instrumen sudah ada pada RPP, tetapi belum diterapkan secara menyeluruh. Dampak dari profil pemahaman asesmen rendah yaitu terjadinya miskonsepsi aspek penilaian kognitif dengan psikomotorik. Guru belum memahami pengembangan rubrik penilaian yang sesuai pada masing-masing penilaian. $\mathrm{Hal}$ ini merugikan bagi peserta didik karena miskonsepsi dan rubrik tidak sesuai mengakibatkan proses asesmen tidak berjalan optimal. Peserta didik yang memiliki kemampuan keterampilan lebih baik dari yang lain tidak dapat teridentifikasi, begitu halnya dengan ranah afektif. Berdampak juga terhadap pelaksanaan pembelajaran selanjutnya yang tidak mengalami perubahan ke arah yang lebih baik dikarenakan tidak berjalan optimal.

\section{Solusi terhadap Profil Kesiapan dan Pemahaman Guru Biologi}

Melihat pentingnya hakekat asesmen, maka profil kesiapan dan pemahaman guru dalam melaksanakan khususnya asesmen psikomotorik dan afektif perlu ditingkatkan melalui berbagai cara. Misalnya sosialisasi mengenai alternatif penerapan asesmen psikomotorik dan afektif selama pembelajaran online perlu dilaksanakan. Meningkatkan pengetahuan literasi asesmen psikomotorik ataupun afektif perlu dilakukan agar menambah wawasan guru khususnya dalam pengembangan rubrik untuk penerapan asesmen selama pembelajaran online. Perlu pembekalan pelatihan intensif tentang asesmen dan pengembangannya oleh pihak sekolah maupun Dinas Pendidikan wilayah setempat. Pelatihan dan workshop ini sangat diperlukan agar tidak terjadi miskonsepsi asesmen psikomotorik dan afektif lebih jauh lagi. Selain itu, perlu dilakukan supervisi sehingga implementasi asesmen psikomotorik dan afektif dalam pembelajaran dapat terpantau dengan baik.

\section{SIMPULAN DAN SARAN}

Hasil kajian penelitian yang telah dilakukan terhadap guru Biologi SMA wilayah 
Kecamatan Comal, maka dapat dikemukakan kesimpulan sebagai berikut profil kesiapan guru terhadap asesmen psikomotorik dan afektif dapat dinyatakan siap untuk melaksanakan asesmen psikomotorik dan afektif. Sedangkan profil pemahaman terhadap asesmen psikomotorik dan afektif secara umum berada pada kategori tingkat rendah. Solusi meningkatkan profil kesiapan dan pemahaman guru Biologi terhadap asesmen psikomotorik dan afektif selama pembelajaran online yaitu dengan pelatihan penggunaan aplikasi pendukung, workshop mengenai pengembangan instrumen dan rubrik asesmen.

Berdasar keseluruhan hasil kajian penelitian yang telah dilakukan, maka dapat dikemukakan beberapa saran kepada pihakpihak terkait. Sekolah dapat melaksanakan supervisi kinerja guru dalam menerapkan asesmen psikomotorik dan afektif, pelatihan meningkatkan pemahaman guru, workshop mengembangkan rubrik penilaian, pelatihan penggunaan aplikasi atau platform penunjang. Guru diharapkan mempelajari asesmen khususnya terkait dengan pengetahuan dan pengembangan rubrik. Selain itu, guru diharapkan mempelajari beberapa aplikasi atau platform yang dapat menunjang penerapan asesmen psikomotorik dan afektif.

\section{UCAPAN TERIMA KASIH}

Penulis menyampaikan terima kasih kepada 1) Dosen pembimbing atas segala bimbingan dan saran yang telah diberikan selama pelaksanaan penelitian sampai dengan pembuatan artikel; dan 2) Guru Biologi SMA wilayah Kecamatan Comal yang telah bersedia menjadi narasumber.

\section{DAFTAR PUSTAKA}

Agustin, D., Kadaritna, N., Tania, L., \& Dll. (2015). Pengembangan Instrumen Asesmen Pengetahuan pada Materi Teori Atom Bohr dan Mekanika Kuantum. Jurnal Pendidikan Dan Pembelajaran Kimia, 4(20), 209-221.

Agustin, I. D., Suryana, Y., \& Nugaraha, A. (2018). Pengembanagan Instrumen Penilaian Kinerja berbasis Outdoor Learning di SD Perkembangan kurikulum di Indonesia. PEDADIDAKTIKA: Jurnal Ilmiah Pendidikan Guru Sekolah Dasar,
5(1), 206-211.

Ahmad, I. F. (2020). Alternative Assessment in Distance Learning in Emergencies Spread of Coronavirus Disease (COVID19). Jurnal Pedagogik, 7(1), 195-222.

Ahmad, M., \& Nasution, D. P. (2018). Analisis Kualitatif Kemampuan Komunikasi Matematis Siswa Yang Diberi Pembelajaran Matematika Realistik. Jurnal Gantang III, 3(2), 83-95. https://doi.org/10.31629/jg.v3i2.471

Basuki, I., \& Hariyanto. (2015). Asesmen Pembelajaran. PT. Remaja Rosdakarya.

Hamdu, G., \& Suryani, I. (2019). The Analysis of Rubric Feasibility Using Video Snippets of Learning Process. Mimbar Sekolah Dasar, 6(2), 239-252. https://doi.org/10.17509/mimbarsd.v0i0.14150

Hidayah, M. (2017). Pengembangan Instrumen Penilaian Psikomotor pada Outdoor Practicum Biologi SMA. Jurnal Penelitian Pendidikan Biologi, 1(2), 143148.

Kurniawati, D., Zulfiani, \& Juaningsih, N. (2014). Profil Penggunaan Authentic Assessment dalam Pembelajaran Biologi di Madrasah Aliyah Se-Kota Bogor. Journal EDUSAINS, 6(1), 43-48.

Lestari, M. R. (2020). Peningkatan Hasil Belajar Biologi Materi Ekologi dengan Mengunakan Metode Kreatif Tim Proyek Siswa Kelas $\mathrm{X}$ IPA 8 SMAN 1 Yogyakarta. Jurnal Ideguru, 5(1), 44-51.

Metin, M. (2013). Teachers' Difficulties in Preparation and Implementation of Performance Task. Educational Sciences: Theory \& Practice, 13(3), 1664-1673. https://doi.org/10.12738/estp.2013.3.1452

Mulyatiningsih, E. (2011). Riset Terapan Bidang Pendidikan dan Teknik. UNY Press.

Nurhaifa, I., Hamdu, G., \& Suryana, Y. (2020). Rubrik Penilaian Kinerja pada Pembelajaran STEM Berbasis Keterampilan 4C. Indonesian Journal of Primary Education, 4(1), 101-110. https://ejournal.upi.edu/index.php/IJPE/ar ticle/view/24742

Rahman, A. (2017). Analisis Pemahaman Guru Tentang Asesmen Pembelajaran Matematika Tingkat SMP Negeri dan Swasta di Kabupaten Maros. Jurnal 
Penelitian Jurusan/Program Studi Penelitian Dan Evaluasi Pendidikan Universitas Negeri Makassar, 1-29. https://doi.org/10.31227/osf.io/yzs76

Rosdiana, T., \& Retnawati, H. (2014). Studi Implementasi Pelaksanaan Penilaian pada Kurikulum 2013. Puspendik, Balitbang Kemendikbud.

Rosidin, U. (2017). Evaluasi dan Asesmen Pembelajaran. Media Akademi.

Sari, K. M., \& Setiawan, H. (2020). Kompetensi Pedagogik Guru dalam Melaksanakan Penilaian Pembelajaran Anak Usia Dini. Jurnal Obsesi : Jurnal Pendidikan Anak Usia Dini, 4(2), 900. https://doi.org/10.31004/obsesi.v4i2.478

Setyowahyudi, R., \& Ferdiyanti, T. (2020). Keterampilan Guru PAUD Kabupaten Ponorogo dalam Memberikan Penguatan Selama Masa Pandemi COVID-19. Jurnal Golden Age, 4(1), 100-111.

Sudrajat, A., Permanasari, A., Zainul, A., \& Buchari, B. (2011). Pengembangan Rubrik Asesmen Kinerja untuk Mengukur Kompetensi Mahasiswa Melakukan Praktikum Kimia Analisis Volumetri. Jurnal Chemica, 12(1), 1-8.

Sugiyono. (2015). Metode Penelitian Pendidikan. ALFABETA.

Taufik, A. (2019). Perspektif tentang Perkembangan Sistem Pembelajaran Jarak Jauh di Kabupaten Kutai Kartanegara Kalimantan Timur. Jurnal Pendidikan \& Konseptual, 3(2), 88-98.

Wahyudi, W. (2012). Assesment Pembelajaran Berbasis Portofolio di Sekolah. Jurnal Visi Ilmu Pendidikan, 2(1), 288-297. https://doi.org/10.26418/jvip.v2i1.370

Yansa, H., \& Retnawati, H. (2021). Identifikasi Praktik dan Hambatan Guru dalam Asesmen Kognitif Matematika di Masa Pandemi COVID-19. Jurnal Elemen, 7(1), 86-99. https://doi.org/10.29408/jel.v7i1.2585

Yusuf, A. M. (2017). Asesmen dan Evaluasi Pendidikan: Pilar Penyedia Informasi dan Kegiatan Pengendalian Mutu Pendidikan. Kencana.

Zuhera, Y., Habibah, S., \& Mislinawati. (2017). Kendala Guru dalam Memberikan Penilaian Terhadap Sikap Siswa dalam Proses Pembelajaran Berdasarkan Kurikulum 2013 di SD
Negeri 14 Banda Aceh. Jurnal Ilmiah Pendidikan Guru Sekolah Dasar, 2(1), 73-87. 